\title{
Faktor Penyebab Pengguna Narkotika di Kalangan Masyarakat
}

\author{
Oktir Nebi ${ }^{1}$ \\ Dosen STIA Nusa Sungai Penuh
}

\begin{abstract}
Abstrak. Penyalahgunaan narkoba juga berpengaruh pada tubuh dan mental-emosional para pemakaianya. Jika semakin sering dikonsumsi, apalagi dalam jumlah berlebih maka akan merusak kesehatan tubuh, kejiwaan dan fungsi sosial di dalam masyarakat. Pengaruh narkoba pada remaja bahkan dapat berakibat lebih fatal, karena menghambat perkembangan kepribadianya. Narkoba dapat merusak potensi diri, sebab dianggap sebagai cara yang "wajar" bagi seseorang dalam menghadapi dan menyelesaikan permasalahan hidup sehari-hari. Tidak terlepas dari berbagai permasalahan yang dihadapi dipandang dari beberapa faktor 1) Frustasi karena tidak mendapatkan pekerjaan 2) Kurangnya informasi tentang bahanya penyalahgunaan sabu-sabu 3) Sifat remaja yang mudah terpengaruh oleh teman atau lingkungan. Dalam penelitian penulisan karya ilmiah ini, tipe penelitian yang digunakan adalah penelitian yuridis normatif. Pendekatan yang digunakan adalah pendekatan konseptual (conceptual approach) dan pendekatan perundang-undangan (statuta approach). Pencegahan-pencegahan yang bisa dilakukan dengan Pencegahan primer (Primary Prevention), Pencegahan sekunder (Secondary Prevention), Pencegahan tertier (Tertiary Prevention).
\end{abstract}

Kata Kunci : Penyebab Penggunaan - Narkotika - Dikalangan Masyarakat.

Abstract. Drug abuse also affects the body and mental-emotional of its users. If it is consumed more often, especially in excess amounts it will damage the health of the body, psyche and social functions in the community. The influence of drugs on adolescents can even have more fatal consequences, because it inhibits his personality development. Narcotics can damage one's potential, because it is considered a "reasonable" way for someone to deal with and solve problems in daily life. Not apart from the various problems faced are seen from several factors 1) Frustration because they do not get a job 2) Lack of information about the danger of sabu-sabu abuse 3) The nature of adolescents who are easily influenced by friends or the environment. In this scientific writing research, the type of research used is normative juridical research. The approach used is the conceptual approach (conceptual approach) and the legal approach (statute approach). Prevention that can be done with Primary Prevention (Primary Prevention), Secondary Prevention (Secondary Prevention), Tertiary Prevention (Tertiary Prevention).

Keywords: Causes of Use - Narcotics - Between Communities

\section{PENDAHULUAN}

Penyalahgunaan dalam penggunaan narkoba adalah pemakain obat-obatan atau zat-zat berbahaya dengan tujuan bukan untuk pengobatan dan penelitian serta digunakan tanpa mengikuti aturan atau dosis yang benar. Dalam kondisi yang cukup wajar/sesuai dosis yang dianjurkan dalam dunia kedokteran saja maka penggunaan narkoba secara terus-menerus akan mengakibatkan ketergantungan, depedensi, adiksi atau kecanduan.

Menurut Reza Iswanto dalam jurnalnya yang berjudul Kebijakan Nonpenal oleh Badan Narkotika Nasional Provinsi Jambi terhadap Penyalahguna Narkotika menyatakan bahwa penyalahgunaan narkotika sekarang ini semakin meningkat dan telah banyak korban yang berjatuhan akibat penyalahgunakan narkotika. ${ }^{2}$

Oleh karena itu, apabila dilhat dari penyalahgunaan narkotika yang semakin berjatuhan, maka wajar saja penyalahgunaan narkoba juga berpengaruh pada tubuh dan mental-emosional para pemakaianya. Jika semakin sering dikonsumsi, apalagi dalam jumlah berlebih maka akan merusak kesehatan tubuh, kejiwaan dan fungsi sosial di dalam masyarakat. Pengaruh narkoba pada remaja bahkan dapat berakibat lebih fatal, karena menghambat perkembangan kepribadianya. Narkoba dapat merusak potensi diri, sebab dianggap sebagai cara yang "wajar" bagi seseorang dalam menghadapi dan menyelesaikan permasalahan hidup seharihari.

\footnotetext{
${ }^{1}$ Oktir Nebi, Dosen STIA Nusa Sungai Penuh

${ }^{2}$ Reza Iswanto, Kebijakan Nonpenal oleh Badan Narkotika Nasional Provinsi Jambi terhadap Penyalahguna Narkotika, Jurnal Wajah Hukum, Volume 2 Nomor 2 (Oktober 2018), hal. 164.
} 
Sabu-sabu merupakan salah satu jenis obat atau zat yang terbuat dari bahan kimia yang di ciptakan untuk halusinasi. Dalam ketentuan perundang-undangan mengenai obat terlarang termasuk juga sabu-sabu di atur dalam Undang-Undang Narkotika yaitu Undang-undang Republik Indonesia No. 35 Tahun 2009. Penggunaan sabu-sabu tersebut tetap di bawah pengawasan dan tanggung jawab dokter dan apoteker.

Bahwa dalam kenyataannya ini sabu-sabu banyak di gunakan masyarakat meskipun telah di sadari bahwa akibat yang timbul dari penyalah gunaan pengguna sabu-sabu tersebut akan membawa pengaruh yang sangat berbahaya bagi manusia terutama bagi pengguna itu sendiri.

Apabila seseorang telah kecanduan terhadap sabu-sabu maka iya senantiasa akan berusaha melakukan apa saja untuk memenuhi kebutuhannya. Hal ini tidak mustahil bagi pecandu yang tidak memiliki uang yang cukup untuk membeli sabu-sabu, akan dapat menimbulkan berbagai tindakan kejahatan seperti pembunuhan, pencurian, perkelahian dan sebagainya.

Faktor penyebab penyalahgunaan sabu-sabu oleh pengguna di kalangan masyarakat, berdasarkan pengamatan penulis di lapangan antara lain:

a. Frustasi karena tidak mendapatkan pekerjaan;

b. Kurangnya informasi tentang bahanya penyalahgunaan sabu-sabu;

c. Sifat remaja yang mudah terpengaruh oleh teman atau lingkungan.

Menurut penulis kalau ini di biarkan akan dapat meresahkan masyarakat, oleh karena itu perlu ada upaya penanggulangan mengutip pendapat Soejono Soekamto "Penanggulangan kriminalitas tidak saja melibatkan unsur-unsur intern Polri tetapi juga unsur di luar Polri dan masyarakat" ${ }^{3 "}$.

\section{Faktor Penyebab Pengguna Narkotika}

a. Faktor Kepribadian

Zat terlarang jenis tertentu dapat membuat pamakainya menjadi lebih berani, keren, percaya diri, kreatif, santai, dan lain sebagainya. Efek keren yang terlihat oleh orang lain tersebut dapat menjadi trend pada kalangan tertentu sehingga orang yang memakai zat terlarang itu akan disebut trendy, gaul, modis, dan sebagainya. Jelas bagi orang yang ingin disebut gaul oleh golongan / kelompok itu, ia harus memakai zat setan tersebut.

b. Faktor Keluarga

Kurangnya kontrol orang tua "orang tua terlalu sibuk sehingga jarang mempunyai waktu untuk mengontrol anggota keluarga, anak yang kurang perhatian keluarga lebih cenderung mencari perhatian diluar dan biasanya mereka juga mencari kesibukan bersama teman-temannya".

Tidak semua penyalahgunaan narkoba yang dilakukan oleh remaja dimuali dari keluarga yang broken home, semua anak mempunyai potensi yang sama untuk terlibat dalam penyalahgunaan narkoba. Penerapan disiplin dan tanggung jawab kepada anak akan mengurangi resiko anak terjebak ke dalam penyalahgunaan narkoba. Anak yang mempunyai tanggung jawab terhadap dirinya, orang tua dan masyarakat akan mempertimbangkan beberapa hal sebelum mencoba-coba menggunakan narkoba

c. Faktor Lingkungan

Lingkungan yang individualistik dalam kehidupan kota besar cenderung kurang peduli dengan orang lain, sehingga setiap orang hanya memikirkan permasalahan dirinya tanpa peduli dengan orang sekitarnya. Akibatnya banayak individu dalam masayarakat kurang peduli dengan penyalahgunaan narkoba yang semakin meluas di kalangan remaja dan anak-anak.

Pengaruh teman atau kelompok juga berperan penting terhadap penggunaan narkoba. Hal ini disebabkan antara lain karena menjadi syarat kemudajan untuk dapat diterima oleh anggota kelompok. Kelompok atau Genk mempunyai kebiasaan perilaku yang sama antar sesama anggota. Jadi tidak aneh bila kebiasaan berkumpul ini juga mengarahkan perilaku yang sama untuk mengkonsumsi narkoba.

d. Faktor Pendidikan

Pendidikan akan bahaya penyalahgunaan narkoba di sekolah-sekolah juga merupakan salah satu bentuk kampanye anti penyalahgunaan narkoba. Kurangnya pengetahuan yang dimiliki oleh siswa-siswi akan bahaya narkoba juga dapat memberikan andil terhadap meluasnya penyalahgunaan narkoba di kalangan pelajar.

${ }^{3}$ Soejono Soekamto, Penanggulangan Kejahatan, Bina Aksara, Jakarta, 1987, hal. 26. 
e. Faktor Populasi Yang Rentan

Remaja masa kini hidup dalam sebuah lingkaran besar, dimana sebagian remaja berada dalam lingkungan yang beresiko tinggi terhadap penyalahgunaan narkoba. Banyak remaja mulai mencoba-coba narkoba, seperti amphetamine-type stimulants (termasuk didalamnya alkohol, tembakau dan obat-obatan yang diminum tanpa resep atau petunjuk dari dokter, serta obat psikoaktif) sehingga menimbulkan berbagai macam masalah pada akhirnya.

\section{Pencegahan Penyalah Gunaan Narkotika}

Upaya yang paling baik dalam menanggulangi penyalahgunaan narkoba tentunya adalah melalui upaya pencegahan yang dilakukan kepada manusia sebagai calon pengguna dan pengadaan narkoba serta pemasarannya. Pencegahan yang dapat dilakukan antara lain melalui:

a. Pencegahan primer (Primary Prevention)

Pencegahan ini dilakukan kepada orang yang belum mengenal Narkoba serta komponen masyarakat yang berpotensi dapat mencegah penyalahgunaan narkoba.Kegiatan-kegiatan yang dilakukan dalam upaya pencegahan ini antara lain:

1) Penyuluhan tentang bahaya narkoba.

2) Penerangan melalui berbagai media tentang bahaya narkoba.

3) Pendidikan tentang pengetahuan narkoba dan bahayanya.

b. Pencegahan Sekunder (Secondary Prevention)

Pencegahan ini dilakukan kepada orang yang sedang coba-coba menyalahgunakan Narkoba serta komponen masyarakat yang berpotensi dapat membantu agar berhenti dari penyalahgunaan narkoba. Kegiatan-kegiatan yang dilakukan dalam upaya pencegahan ini antara lain:

1) Deteksi dini anak yang menyalahgunaan narkoba.

2) Konseling.

3) Bimbingan sosial melalui kunjungan rumah.

4) Penerangan dan Pendidikan pengembangan individu .

5) (life skills) antara lain tentang ketrampilan berkomunikasi, ketrampilan menolak tekanan orang lain dan ketrampilan mengambil keputusan dengan baik.

c. Pencegahan Tertier (Tertiary Prevention)

Pencegahan ini dilakukan kepada orang yang sedang menggunakan narkoba dan yang pernah/mantan pengguna narkoba, serta komponen masyarakat yang berpotensi dapat membantu agar berhenti dari penyalahgunaan narkoba dan membantu bekas korban naroba untuk dapat menghindariKegiatan-kegiatan yang dilakukan dalam upaya pencegahan ini antara lain:

1) Konseling dan bimbingan sosial kepada pengguna dan keluarga serta kelompok lingkungannya.

2) Menciptakan lingkungan yang kondusif bagi bekas pengguna agar mereka tidak terjerat untuk kembali sebagai pengguna narkoba.

Selain pencegahan yang telah disebutkan, maka yang paling berpotensi untuk dapat menghindari penyalahgunaan narkoba adalah dari lingkungan keluarga.

\section{Pengertian Narkotika}

Secara umum yang di maksud dengan narkotika adalah jenis zat yang dapat menimbulkan pengaruhpengaruh tertentu bagi orang-rang yang menggunakannya yaitu dengan cara memasukkan ke dalam tubuh. Istilah narkotika yang di pergunakan adalah "drugs" yaitu sejenis zat yang apabiladi pergunakan akan membawa efek dan pengaruh-pengaruh tertentu pada tubuh si pemakai.

Menurut Soedjono Dirjosisworo, pengertian narkotika adalah:

Zat yang bisa menimbulkan pengaruh-pengaruh tertentu bagi mereka yang menggunakannya dengan memasukan ke dalam tubuh, pengaruh tersebut berupa pembiusan, hilangnya asa sakit, rangsangan semangat dan halusinasi atau timbulnya khyalan-khayalan. Sifat tersebut yang di ketahui dan di temukan dalam dunia medis bertujuan untuk di manfaatkan bagi pengobatan kepentingan manusia seperti bidang pembedahan, menghilangkan rasa sakit dan lain-lain ${ }^{4}$. 
Sehubungan dengan pengertian narkotika menurut Sudarto sebagaimana dalam bukunya Kapita selekta hukum pidana menyatakan bahwa : perkataan narkotika berasal dari perkataan yunani "narki" yang berarti terbius sehingga tidak merasa apa-apa.

Definisi lain dari biro bea dan cukai amerika serikat dalam buku "Narcotic Identification Manual" sebagaimana di kutip Djoko Prakoso, Bambang Riyadi dan Mukhsin di katakan :

Bahwa yang di maksud denngan narkotika adalah, candu, ganja, kokain, zat-zat yang bahan mentahnya di ambil dari benda-benda tersebut, yakni morphin, heroin, codein, hasish, cocain dan termasuk juga narkotika sintetis yang menghasilkan zat-zat obat-obat yang tergolong dalam hallucinogen dan stimulant 5 .

\section{Ketentuan Pidana Menurut Undang-Undang No.35 Tahun 2009 Tentang Narkotika \\ Pasal 111}

\section{Ayat 1}

Setiap orang yang tanpa hak atau melawan hukum menanam, memelihara, memiliki, menyimpan, menguasai, atau menyediakan narkotika golongan I dalam bentuk tanaman dipidana dengan pidana paling singkat 4 tahun dan paling lama 12 tahun dan pidana denda paling sedikit Rp.800.000.000,- (delapan ratus juta rupiah) dan paling banyak Rp.8.000.000.000, (delapan miliar rupiah).

\section{Ayat 2}

Dalam hal perbuatan menanam, memelihara, memiliki, menyimpan, menguasai, atau menyediakan narkotika golongan I dalam bentuk tanaman sebagaimana dimaksud ayat (1) beratnya melebihi 1 kilogram atau melebihi 5 batang pohon, pelaku dipidana dengan pidana penjara seumur hidup atau pidana paling singkat 5 tahun dan paling lama 20 tahun dan dipidana denda maksimum sebagaimana dimaksud pada ayat (1) ditambah $1 / 3$ (sepertiga).

\section{Pasal 112}

\section{Ayat 1}

Setiap orang yang tanpa hak atau melawan hukum memiliki, menyimpan, menguasai, atau menyediakan narkotika golongan I bukan tanaman di pidana dengan pidana penjara paling singkat 4 tahun dan paling lama 12 tahun dan pidana denda paling sedikit Rp.800.000.000,- (delapan ratus juta rupiah) dan paling banyak Rp.8.000.000.000, (delapan miliar rupiah).

\section{Ayat 2}

Dalam hal perbuatan memiliki, menyimpan, menguasai, atau menyediakan narkotika golongan I bukan tanaman sebagaimana dimaksud pada ayat (1) beratnya melebihi 5 gram pelaku dipidana dengan pidana penjara seumur hidup atau pidana penjara paling singkat 5 tahun dan paling lama 20 tahun dan pidana denda maksimum sebagaimana dimaksud pada ayat (1) di tambah 1/3 (sepertiga).

\section{Pasal 113}

\section{Ayat 1}

Setiap orang yang tanpa hak atau melawan hukum memproduksi, mengimpor, mengekspor atau menyalurkan narkotika golongan I dipidana dengan pidana penjara paling singkat 5 tahun dan dipidana denda paling sedikit Rp.1.000.000.000,- (satu miliar) dan paling banyak Rp.10.000.000.000,- (sepuluh miliar).

\section{Ayat 2}

Dalam hal perbuatan memproduksi mengimpor, mengekspor atau menyalurkan narkotika golongan I sebagaimana dimaksud pada ayat (1) dalam bentuk tanaman beratnya melebihi 1 kilogram atau melebihi 5 batang pohon atau dalam bentuk bukan tanaman beratnya melebihi 5 gram pelaku dipidana dengan pidana mati, pidana penjara seumur hidup atau pidana penjara paling singkat 5 tahun dan paling lama 20 tahun dan pidana denda maksimum sebagaimana dimaksud ayat (1) di tambah 1/3 (sepertiga).

\section{Pasal 114}

\section{Ayat 1}

${ }^{5}$ Djoko Prakoso, Bambang Riyadi Lang Dan Muksi, Kejahatan-Kejahatan Yang Merugikan Dan Membahayakan Negara, Bina Aksara, Hal.480. 
Setiap orang yang tanpa hak atau melawan hukum menawarkan untuk dijual, menjual, membeli, menerima, menjadi perentara dalam jual beli, menukar atau menyerahkan narkotika golongan I dipidana dengan pidana penjara seumur hidup atau pidana penjara paling singkat 5 tahun dan paling lama 20 tahun dan pidana denda paling sedikit Rp.1.000.000.000,- (satu miliar) dan paling banyak Rp.10.000.000.000,(sepuluh miliar).

\section{Ayat 2}

Dalam hal perbuatan menawarkan untuk dijual, menjual, membeli, menjadi perantara dalam jual beli, menukar, menyerahkan atau menerima narkotika golongan I sebagaimana dimaksud pada ayat (1) yang dalam bentuk tanaman beratnya melebihi 1 kilogram atau melebihi 5 batang pohon dalam bentuk bukan tanaman bratnya 5 gram pelaku dipidana dengan pidana mati pidana penjara seumur hidup pidana penjara paling singkat 6 tahun dan paling lama 20 tahun dan pidana denda maksimum sebagaimana dimaksud ayat (1) di tambah $1 / 3$ (sepertiga).

\section{Pasal 115}

\section{Ayat 1}

Setiap orang yang tanpa hak atau melawan hukum membawa, mengirim, mengangkut, atau menstrasito narkotika golongan I dipidana dengan pidana penjara paling singkat 4 tahun dan paling lama 12 tahun dan dipidana denda paling sedikit Rp.800.000.000,- (delapan ratus juta rupiah) dan paling banyak Rp.8.000.000.000, (delapan miliar rupiah).

\section{Ayat 2}

Dalam hal perbuatan membawa, mengirim, mengangkut, atau menstransito narkotika golongan I sebagaimana dimaksud pada ayat (1) dalam bentuk tanaman beratnya 1 kilogram atau melebihi 5 batang pohon beratnya melebihi 5 gram, pelaku dipidana dengan pidana penjara seumur hidup atau pidana penjara paling singkat 5 tahun dan paling lama 20 tahun dan pidana denda maksimum sebagaimana dimaksud pada ayat (1) ditambah $1 / 3$ (sepertiga).

\section{Pasal 116}

\section{Ayat 1}

Setiap orang tanpa hak atau melawan hukum menggunakan narkotika golongan I terhadap orang lain atau memberikan narkotika golongan 1 untuk digunakan orang lain, dipidana dengan pidana penjara paling singkat 5 tahun dan paling lama 15 tahun dan pidana denda paling sedikit Rp.1.000.000.000,- (satu miliar) dan paling banyak Rp.10.000.000.000,- (sepuluh miliar).

\section{Ayat 2}

Dalam hal penggunakan narkotika terhadap orang lain atau pemberian narkotika golongan I untuk digunakan orang lain sebagaimana dimaksud pada ayat (1) mengakibatkan orang lain mati atau cacat permanen, pelaku dipidana dengan pidana mati, pidana penjara seumur hidup atau pidana penjara paling singkat 5 tahun dan paling lama 20 tahun dan pidana denda maksimum sebagaimana dimaksud pada ayat (1) ditambah $1 / 3$ (sepertiga).

\section{Pasal 117}

\section{Ayat 1}

Setiap orang yang tanpa hak atau melawan hukum memiliki, menyimpan, menguasai, atau menyediakan narkotika golongan II dipidana dengan pidana penjara paling singkat 3 tahun dan paling lama 10 tahun dan pidana denda paling sedikit Rp.600.000.000,- (eam ratus juta Rupiah) dan paling banyak Rp.5.000.000.000,- (lima miliar rupiah).

\section{Ayat 2}

Dalam hal perbuatan memiliki, , menyimpan, menguasai, atau menyediakan narkotika golongan II sebagaimana dimaksud pada ayat (1) beratnya melebihi 5 gram pelaku dipidana dengan pidana penjara paling singkat 5 tahun dan paling lama 15 tahun dan pidana denda maksimum sebagaimana dimaksud pada ayat (1) ditambah $1 / 3$ (sepertiga).

\section{Pasal 118}

\section{Ayat 1}

Setiap orang yang tanpa hak atau melawan hukum memproduksi, mengimpor, mengekspor atau menyalurkan narkotika golongan II dipidana dengan pidana penjara paling singkat 4 tahun dan paling lama 
12 tahun dan pidana denda paling sedikit Rp.800.000.000,- (delapan ratus juta rupiah) dan paling banyak Rp.8.000.000.000, (delapan miliar rupiah).

\section{Ayat 2}

Dalam hal perbuatan memproduksi, mengimpor, mengekspor atau menyalurkan narkotika golongan II sebagaimana dimaksud pada ayat (1) beratnya melebihi 5 gram pelaku dipidana dengan pidana mati, pidana penjara seumur hidup atau pidana penjara paling singkat 5 tahun dan paling lama 20 tahun dan pidana denda maksimum sebagaimana dimaksud pada ayat (1) ditambah 1/3 (sepertiga).

\section{Pasal 119}

\section{Ayat 1}

Setiap orang yang tanpa hak atau melawan hukum menawarkan untuk dijual, menjual, membeli, menerima, menjadi perentara dalam jual beli, menukar atau menyerahkan narkotika golongan II dipidana dengan pidana penjara paling singkat 4 tahun dan paling lama 12 tahun dan pidana denda paling sedikit Rp.800.000.000,- (delapan ratus juta rupiah) dan paling banyak Rp.8.000.000.000, (delapan miliar rupiah).

\section{Ayat 2}

Dalam hal perbuatan menawarkan untuk dijual, menjual, membeli, menerima, menjadi perentara dalam jual beli, menukar atau menyerahkan narkotika golongan II sebagaimana dimaksud pada ayat (1) beratnya melebihi 5 gram pelaku dipidana dengan pidana mati, pidana penjara seumur hidup atau pidana penjara paling singkat 5 tahun dan paling lama 20 tahun dan pidana denda maksimum sebagaimana dimaksud pada ayat (1) ditambah 1/3 (sepertiga).

\section{Pasal 120}

\section{Ayat 1}

Setiap orang yang tanpa hak atau melawan hukum membawa, mengirim, mengangkut, atau menstrasito narkotika golongan II dipidana dengan pidana penjara paling singkat 3 tahun dan paling lama 10 tahun dan dipidana denda paling sedikit Rp.600.000.000,- (eam ratus juta Rupiah) dan paling banyak Rp.5.000.000.000,- (lima miliar rupiah).

\section{Ayat 2}

Dalam hal perbuatan membawa, mengirim, mengangkut, atau menstrasito narkotika golongan II sebagaimana dimaksud pada ayat (1) beratnya melebihi 5 gram maka pelaku dipidana dengan pidana penjara paling singat 5 tahun dan paliang lama 15 tahun dan pidana denda maksimum sebagaimana dimaksud pada ayat (1) ditambah $1 / 3$ (sepertiga).

\section{Pasal 121}

\section{Ayat 1}

Setiap orang yang tanpa hak atau melawan hukum menggunakan narkotika golongan II terhadap orang lain atau memberikan narkotika golongan II untuk digunakan orang lain dipidana dengan pidana penjara paling singkat 4 tahun dan paling lama 12 tahun dan dipidana denda paling sedikit Rp.800.000.000,(delapan ratus juta rupiah) dan paling banyak Rp.8.000.000.000, (delapan miliar rupiah).

\section{Ayat 2}

Dalam hal penggunaan narkotika terhadap orang lain atau pemberian narkotika golongan II untuk digunakan orang lain sebagaimana dimaksud ayat (1) mengakibatkan orang lain mati atau cacat permanen, pelaku dipidana dengan pidana mati, pidana penjara seumur hidup atau pidana penjara paling singkat 5 taun dan paling lama 20 tahun dan pidana denda maksimum sebagaimana dimaksud pada ayat (1) ditambah $1 / 3$ (sepertiga).

\section{Pasal 122}

\section{Ayat 1}

Setiap orang yang tanpa hak atau melawan hukum memiliki, menyimpan, menguasai, atau menyediakan narkotika golongan III dipidana dengan pidana penjara paling singkat 2 tahun dan paling lama 7 tahun dan pidana denda paling sedikit Rp.400.000.000,- (empat ratus juta rupiah) dan paling banyak Rp.3.000.000.000,- (tiga miliar rupiah).

\section{Ayat 2}

Setiap orang yang tanpa hak atau melawan hukum memiliki, menyimpan, menguasai, atau menyediakan narkotika golongan III sebagaimana dimaksud ayat (1) beratnya melebihi 5 gram pelaku 
dipidana dengan pidana penjara paling singkat 3 tahun dan paling lama 10 tahun dan pidana denda maksimum sebagaimana dimaksud ayat (1) ditambah 1/3 (sepertiga).

\section{Pasal 123}

\section{Ayat 1}

Setiap orang yang tanpa hak atau melawan hukum memproduksi, mengimpor, mengekspor atau menyalurkan narkotika golongan III dipidana dengan pidana penjara paling singkat 3 tahun dan paling lama 10 tahun dan pidana denda paling sedikit Rp.600.000.000,- (enam ratus juta rupiah) dan paling banyak Rp.5.000.000.000, (lima miliar rupiah).

\section{Ayat 2}

Dalam hal perbuatan memproduksi, mengimpor, mengekspor atau menyalurkan narkotika golongan III sebagaimana dimaksud ayat (1) beratnya melebihi 5 gram pelaku dipidana dengan pidana penjara paling singkat 5 tahun dan paling lama 15 tahun dan pidana denda maksimum sebagaimana dimaksud ayat (1) ditambah $1 / 3$ (sepertiga).

\section{Pasal 124}

\section{Ayat 1}

Setiap orang yang tanpa hak atau melawan hukum menawarkan untuk dijual, menjual, membeli, menerima, menjadi perentara dalam jual beli, menukar atau menyerahkan narkotika golongan III dipidana dengan pidana penjara paling singkat 3 tahun dan paling lama 10 tahun dan pidana denda paling sedikit Rp.600.000.000,- (enam ratus juta rupiah) dan paling banyak Rp.5.000.000.000, (lima miliar rupiah).

\section{Ayat 2}

Dalam hal perbuatan menawarkan untuk dijual, menjual, membeli, menerima, menjadi perentara dalam jual beli, menukar atau menyerahkan narkotika golongan III sebagaimana dimaksud ayat (1) beratnya melebihi 5 gram pelaku dipidana dengan pidana penjara paling singkat 5 tahun dan paling lama 15 tahun dan pidana denda maksimum sebagaimana dimaksud ayat (1) ditambah $1 / 3$ (sepertiga).

\section{Pasal 125}

\section{Ayat 1}

Setiap orang yang tanpa hak atau melawan hukum membawa, mengirim, mengangkut, atau menstrasito narkotika golongan III dipidana dengan pidana penjara paling singkat 2 tahun dan paling lama 7 tahun dan dipidana denda paling sedikit Rp.400.000.000,- (empat ratus juta rupiah) dan paling banyak Rp.3.000.000.000, (tiga miliar rupiah).

\section{Ayat 2}

Dalam hal perbuatan melawan hukum hukum membawa, mengirim, mengangkut, atau menstrasito narkotika golongan III sebagaimana dimaksud ayat (1) beratnya melebihi 5 gram pelaku dipidana dengan pidana penjara paling singkat 3 tahun dan paling lama 10 tahun dan pidana denda maksimum sebagaimana dimaksud ayat (1) ditambah $1 / 3$ (sepertiga).

\section{Pasal 126}

\section{Ayat 1}

Setiap orang yang tanpa hak atau melawan hukum menggunakan narkotika golongan III terhadap orang lain atau memberikan narkotika golongan III untuk digunakan orang lain dipidanda dengan pidana penjara paling singkat 3 tahun dan paling lama 10 tahun dan pidana denda paling sedikit Rp.600.000.000,(enam ratus juta tupiah) dan paling banyak Rp.5.000.000.000 (lima miliar rupiah).

\section{Ayat 2}

Dalam hal penggunaan narkotika terhadap orang lain atau pemberian narkotika golongan III untuk digunakan orang lain sebagaimana dimaksud ayat (1) mengakibatkan orang lain mati atau cacat permanen, pelaku dipidana dengan pidana penjara paling singkat tahun dan paling lama 15 tahun dan pidana denda maksimum sebagaimana dimaksud ayat (1) ditambah 1/3 (sepertiga).

\section{Pasal 127}

\section{Ayat 1}

Setiap penyalah guna :

a. Narkotika golongan I bagi diri sendiri dipidana dengan pidana penjara paling lama 4 tahun.

b. Narkotika golongan II bagi diri sendiri dipidana dengan pidana penjara paling lama 2 tahun.

c. Narkotika golongan III bagi sendiri dipidana dengan pidana penjara paling lama 1 tahu, 


\section{Ayat 2}

Dalam memutus perkara sebagaimana dimaksud pada ayat (1) hakim wajib memperhatikan ketentuan sebagaimana dimaksud dalam pasal 54,pasal 55 dan pasal 103.

Ayat 3

Dalam hal penyalah guna sebagaimana dimaksud pada ayat (1) dapat dibuktikan atau terbukti sebagai korban penyalahgunaan narkotika,penyalah guna tersebut wajib menjalani rehabilitas medis dan rehabilitas sosial.

\section{Pasal 128}

\section{Ayat 1}

Orang tua atau wali dari pecandu yang belum cukup umur sebagaimana dimaksud dalam Pasal 55 ayat (1) yang sengaja tidak melapor, dipidana dengan pidana kurungan paling lama 6 bulan atau pidana denda paling banyak Rp.1.000.000,- (satu juta rupiah).

\section{Ayat 2}

Pecandu narkotika yang belum cukup umur telah dilaporkan oleh orang tua atau walinya sebagaimana dimaksud dalam Pasal 55 ayat (1) tidak dituntut pidana.

\section{Ayat 3}

Pecandu narkotika yang telah cukup umur sebagaimana dimaksud dalam pasal 55 ayat (2) yang sedang menjalani rehabilitasi medis 2 kali massa perawatan dokter di rumah sakit dan atau lembaga rehabilitasi medis yang ditunjuk oleh pemerintah tidak dituntut pidana.

\section{Ayat 4}

Rumah sakit dan atau lembaga rehabilitas medis sebagaimana dimaksud pada ayat (3) harus memenuhi standar kesehatan yang di tetapkan oleh menteri.

\section{Pasal 129}

Dipidana dengan pidana penjara paling singkat 4 tahun dan paling lama 20 tahun dan denda paling banyak Rp.5.000.000.000,- (lima miliar rupiah) setiap orang yang tanpa hak atau melawan hukum :

a. Memiliki, menyimpan, menguasai, atau menyediakan prekursor narkotika untuk pembuatan narkotika.

b. Memproduksi, mengimpor, mengekspor atau menyaurkan prekursor narkotika untuk pembuatan narkotika.

c. Menawarkan untuk dijual, menjual, membeli, menerima, menjadi perantara dalam jual beli, menukar atau menyerahkan prekursor narkotika untuk pembuatan narkotika..

d. Membawa, mengirim, mengangkut atau mentransito prekursor narkotika untuk pembuatan narkotika.

\section{Pasal 130}

\section{Ayat 1}

Dalam hal tindak pidana sebagaimana dimaksud dalam Pasal 111, 112, 113, 114, 115, 116, 117, 118 , 119, 120, 121, 122, 123, 124, 125, 126 dan Pasal 129 dilakukan korporasi, selain pidana penjara dan denda terhadap korporasi berupa pidana penjara dan denda terhadap pengurusnya, pidana yang dapat di jatuhkan terhadap korporasi berupa pidana denda dengan pemberatan 3 kali dari pidana denda sebagaimana dimaksud dalam Pasal-pasal tersebut.

\section{Ayat 2} berupa :

Selain pidana denda sebagaimana dimaksud pada ayat (1) korporasi dapat dijatuhi pidana tambahan

a. Pencabutan izin usaha

b. Pencabutan status badan hukum.

\section{DAFTAR PUSTAKA}

Soejono Soekamto, Penanggulangan Kejahatan, Bina Aksara, Jakarta, 1987.

Soedjono Dirjosisworo, Hukum Narkotika Indonesia, PT.Citra Aditya Bakti, Bandung, 1990.

Djoko Prakoso, Bambang Riyadi Lang Dan Muksi, Kejahatan-Kejahatan Yang Merugikan Dan Membahayakan Negara, Bina Aksara.

Reza Iswanto, Kebijakan Nonpenal oleh Badan Narkotika Nasional Provinsi Jambi terhadap Penyalahguna Narkotika, Jurnal Wajah Hukum, Volume 2 Nomor 2 (Oktober 2018)

Undang-Undang Nomor 35 Tahun 2009 Tentang Narkotika. 